\title{
Dietary Choline Deficiency causes DNA Strand Breaks and Alters Epigenetic Marks on DNA and Histones
}

\author{
Steven H. Zeisel, M.D., Ph.D. \\ Nutrition Research Institute, School of Public Health and School of Medicine, The University of \\ North Carolina at Chapel Hill, Kannapolis, NC 28081, phone (704) 250-5003 fax (704) 250-5001 \\ Steven H. Zeisel: steven_zeisel@unc.edu
}

\begin{abstract}
Dietary choline is an important modulator of gene expression (via epigenetic marks) and of DNA integrity. Choline was discovered to be an essential nutrient for some humans approximately one decade ago. This requirement is diminished in young women because estrogen drives endogenous synthesis of phosphatidylcholine, from which choline can be derived. Almost half of women have a single nucleotide polymorphism that abrogates estrogen-induction of endogenous synthesis, and these women require dietary choline just as do men. In the US, dietary intake of choline is marginal. Choline deficiency in people is associated with liver and muscle dysfunction and damage, with apoptosis, and with increased DNA strand breaks. Several mechanisms explain these modifications to DNA. Choline deficiency increases leakage of reactive oxygen species from mitochondria consequent to altered mitochondrial membrane composition and enhanced fatty acid oxidation. Choline deficiency impairs folate metabolism, resulting in decreased thymidylate synthesis and increased uracil misincorporation into DNA, with strand breaks resulting during error-prone repair attempts. Choline deficiency alters DNA methylation, which alters gene expression for critical genes involved in DNA mismatch repair, resulting in increased mutation rates. Any dietary deficiency which increases mutation rates should be associated with increased risk of cancers, and this is the case for choline deficiency. In rodent models, diets low in choline and methyl-groups result in spontaneous hepatocarcinomas. In human epidemiological studies, there are interesting data that suggest that this also may be the case for humans, especially those with SNPs that increase the dietary requirement for choline.
\end{abstract}

Keywords

Choline; DNA; SNP; mitochondria; reactive oxygen species; epigenetics; methylation

Choline is an essential nutrient for most people [1], and in some areas of the world (including the USA) dietary intake is marginal [2]. Dietary choline deficiency is associated with important modifications to the structure of DNA and chromosomes. These effects of choline deficiency result in changes in gene expression, genomic instability and carcinogenesis.

() 2011 Elsevier B.V. All rights reserved.

Publisher's Disclaimer: This is a PDF file of an unedited manuscript that has been accepted for publication. As a service to our customers we are providing this early version of the manuscript. The manuscript will undergo copyediting, typesetting, and review of the resulting proof before it is published in its final citable form. Please note that during the production process errors may be discovered which could affect the content, and all legal disclaimers that apply to the journal pertain. 


\section{Choline Requirements}

Choline is needed to form membranes (phosphatidylcholine and sphingomyelin are cholinecontaining phospholipids), it is an important methyl-group donor (choline metabolism intersects with folate metabolism at the methylation of homocysteine to form methionine) and it is needed to form the neurotransmitter acetylcholine [3]. Choline can be made available from endogenous synthesis of phosphatidylcholine in the liver [4], and is a part of the diet; the food sources of choline have been comprehensively catalogued by the United States Department of Agriculture (see www.ars.usda.gov/SP2UserFiles/Place/12354500/Data/Choline/Choln02.pdf) [5, 6]. Many of the foods that have high choline content also are high in fats or cholesterol (e.g. eggs) and people are decreasing their intake of these foods such that today only a minority of people achieve the recommended dietary Adequate Intake [1] for choline [2]. A number of studies report that $20-25 \%$ of Americans eat only a portion of the recommended adequate intake for choline $(<203 \mathrm{mg} / \mathrm{d}$ in the Framingham Heart Study [7], $<217 \mathrm{mg} / \mathrm{d}$ in the Atherosclerosis Risk In Communities study [8,9] and <293 mg/d in the Nurse's Health Study [10]; Adequate Intake is $450-550 \mathrm{mg} /$ day [1]).

Almost all men and postmenopausal women, when fed a diet low in choline, develop fatty liver, liver damage and/or muscle damage, as well as increased apoptosis in tissues [11, 12], but less than half of premenopausal women develop such organ dysfunction when fed a low choline diet [11]. Premenopausal women have a lower requirement for choline because estrogen induces PEMT (phosphatidylethanolamine- $N$-methyltransferase) [13], the gene in liver enabling endogenous biosynthesis of choline moiety (as part of phosphatidylcholine). Postmenopausal women treated with estrogen had a dietary choline requirement similar to that of premenopausal women [14]. However, almost half of women in the USA have one or more single nucleotide polymorphisms (SNPs) in the PEMT gene, and this makes them unable to induce this gene with estrogen [15], thereby abrogating much of endogenous production of choline. These women develop organ dysfunction on a low choline diet [16]. There are several other common SNPs in genes of choline and folate metabolism (PEMT, $C H D H, B H M T$ and MTHFD1) that alter dietary choline requirements in men and women $[16,17]$.

Our understanding of dietary intake and the factors that influence dietary requirements for choline, suggest that many people have low or marginal intakes of this nutrient. This is important for scientists interested in diet and DNA mutations, as one consequence of this choline insufficiency is alteration of the structure of DNA and histones resulting in DNA strand breaks in humans [12], and in rats [18, 19]. The mechanisms for these strand breaks are not fully elucidated but are probably related to oxidative damage, folate deficiencyrelated uracil misincorporation, and to altered DNA methylation and subsequent effects on DNA repair processes.

\section{Choline and Oxidative DNA damage}

Oxidative damage to DNA, as assessed by the formation of 8-oxodeoxyguanosine [20, 21], apurinic/apyrimidinic sites [22] and Ogg1-sensitive sites [22] in DNA accumulate when rats are deprived of choline. The oxidative stress to DNA is reflected in changes in genes for DNA repair enzymes with significant increases in expression of apurinic/apyrimidinic endonuclease 1 (Ape), poly(ADP-ribose) polymerase 1 ( Parp), and DNA polymerase beta $(P o l \beta)$, 8-oxyguanine DNA glycolase $1(\mathrm{Ogg} 1)$ and O6-methylguanine-DNA methyl transferase [21,22]. Choline deficiency and resulting liver cell death [23] causes an inflammatory response, and elicited neutrophils and macrophages generate reactive oxygen and nitrogen species [24] that can directly induce DNA base oxidation and deamination. 
However, In addition, hepatocytes grown in culture medium low in choline overproduce free radicals in the absence of an inflammatory response [25, 26]. Thus, overproduction of reactive oxygen species (ROS) in choline deficiency is likely due to abnormal mitochondrial function; in rats, choline deficient mitochondria leak large amounts of ROS [25, 27-30]. Excess ROS triggers apoptosis in many tissues in both rodent and human studies [12, 23, 25, $31,32]$. There are a number of mechanisms whereby choline deficiency induces mitochondrial dysfunction and over generation of ROS. Choline deficiency alters the composition of mitochondrial membranes; rats fed low choline diets oxidize cardiolipin in mitochondrial membranes, and have lower phosphatidylethanolamine and phosphatidylcholine concentrations in these membranes [25, 33]. In addition, the phosphatidylcholine in mitochondria consists of species with longer chain fatty acids that are present in controls [34]. These membrane changes are associated with mitochondrial membrane potential decreases $[30,35]$ and reduced activity of complex I of the respiratory chain (NADH-ubiquinone oxidoreductase) [33,34] (this can be restored by adding cardiolipin to the choline deficient mitochondria [33]; cardiolipin is required for electron transfer by complex I $[36,37])$. Decreased ATP production by mitochondria was also seen in rats fed a choline deficient diet [38], or choline-methionine deficient diet [39]. This could be caused by a proton leak secondary to abnormal membrane function [40] or by abnormally high expression of $U C P 2$ (uncoupling protein-2) in choline deficient hepatocytes [39]. It is interesting that, in mice, deletion of a gene in choline metabolism (Chdh; choline dehydrogenase is an inner mitochondrial leaflet protein that catalyzes conversion of choline to betaine) causes gross distortion of mitochondrial morphology and decreased mitochondrial function including decreased ATP production, uncoupling and abnormal membrane polarization [41].

These changes in mitochondrial function are exacerbated by the changes that choline deficiency causes in metabolism. During choline deficiency, hepatocytes are supplied with large amounts of fatty acids which increase mitochondrial respiratory activity [42] and oxygen utilization [29]. The combination of excess activity in pathways of lipid metabolism with increased generation of ROS forms lipid peroxides in nuclear and mitochondrial membranes [43-45] which are sources of free radicals in the nucleus that modify DNA [46].

\section{Choline and Folate-related DNA damage}

Because folate metabolism and choline metabolism are intermingled, perturbing metabolism of choline results in compensatory changes in folate-related metabolic pathways [47-49]. Thus, diets that are low in choline also result in decreased tissue folate [47, 48]. Folate is a cofactor for metabolic pathways that methylate homocysteine, forming methionine, but also folate is a cofactor for the formation of thymidylate needed for DNA synthesis [19, 50, 51]. When thymine is not available, uracil is misincorporated into DNA [19], and subsequent efforts to repair the mistake can result in errors that cause DNA strand breaks to occur at folate-sensitive fragile sites [19,52-55]. Though this mechanism for strand breaks that occur in choline deficiency remains a possibility, humans who were deprived of choline but supplemented with folic acid still developed strand breaks in DNA [12].

\section{Choline and Epigenetic Marks}

Choline is an important source of methyl-groups for synthesis of $S$-adenosylmethionine which is needed for epigenetic marking of DNA and histones. [56, 57]. A choline deficientlow methionine diet in rats results in global hypomethylation of hepatic DNA [58]. Choline deficiency also results in altered methylation status of DNA cytosines, usually at repetitive elements such as cytosine-guanine repeats ( $\mathrm{CpG}$ islands) in the promoters of specific genes $[57,59]$. Choline and methyl deficiency can cause hypomethylation of some genes while 
paradoxically hypermethylating certain other genes (including tumor suppressor genes) by increasing the recruitment of methyl-binding proteins to the $\mathrm{CpG}$ islands $[12,58,60,61]$. This occurs in part because of limitation in the availability of $S$-adenosylmethionine, but also because several DNA methyltransferases (Dnmt1 and 3a) are regulated via methylation of their promoter regions [62]. Depending on the balance between these two mechanisms near a specific gene, choline deficiency can be associated with reproducible hypo- or hypermethylation of a specific codon in that gene. Choline deficiency also changes the expression and activity of G9a histone methylase with direct consequences for global and gene specific levels of histone methylation [56]. These changes in gene methylation can permanently alter phenotype; in the Agouti mouse, maternal diet (choline, folate and methionine) during pregnancy directly influences the coat color of pups [63]. Similarly, maternal diet during pregnancy determines whther pups have straihght or kinky tails in the Axin-fused mouse [64],

Choline influences DNA methylation (see above) which in turn influences genomic stability [65]. As noted above, choline availability modulates expression of Dnmt1 and Dnmt3a [62]. Mice (or cultured cells) with partial loss of function of Dnmt 1 have increased mutation rates (by as much as 10-fold) at specific regions of DNA (microsatellite repeats) [65, 66]. Similarly, genomic stability was decreased in Dnmt 1 single or Dnmt3a/Dnmt $3 b$ double knockout cells [67]. The likely mechanism for these Dnmt-associated effects on mutation rates are defects in mismatch repair (MMR) due to decreased levels of protein complexes (MutLa and MutSa) that are needed to complete DNA repair [65]. Choline also influences histone methylation (see above), which in turn is important for the activation of DNA damage response pathways that consist of complex signaling networks that detect and repair DNA damage before the cell divides [68]. Histone methylation also is important in DNA double strand break repair because $53 B P 1$, which is required for proper homologous recombination, is recruited to sites of DNA damage by methylated histones [69].

\section{Choline and Cancer}

Increased mutation rates are usually associated with increased risk for cancer formation. In addition, as discussed earlier, choline modulates epigenetic marking of genes, and choline deficiency is correlated with the silencing of several tumor suppressor genes responsible for DNA repair (BRCA1, hMLH1) [21], cell cycle regulation $(p 15, p 16)$ [70] and carcinogen metabolism (GSTP1) [71]. Indeed, choline deficiency is one of the few single nutrient deficiencies that causes increased spontaneous carcinogenesis. Rats and mice fed a choline (and methyl) deficient diet first develop fatty liver, progress to liver fibrosis, followed by development of foci of abnormal enzyme-altered hepatocytes that are similar to those induced during initiation of cancer with one of many different chemical carcinogens [7276]. In choline deficiency these altered foci of hepatocytes, which express $\gamma-$ glutamyltranspeptidase [77] and the placental form of glutathione S-transferase [78], precede the formation of adenomas and hepatocellular carcinomas [79]. A diet containing $0.8 \%$ added choline completely prevents the development of cancer in experimental animals [80]. Choline deficiency also sensitized rodents to hepatic carcinogens such as aflatoxin B1 [81] and breast carcinogens such as dimethylbenz[a]anthracene (DMBA) [81], medroxyprogesterone acetate (MPA) [82] and procarbazine [83]. For example, rats fed a choline-deficient/methionine-low diet were sensitized to aflatoxin B1 with greatly increased hepatocarcinogenesis and reduced time to first tumors [84].

Given the body of research linking dietary choline (methyl) deficiency to increased mutation rates, strand breaks and liver cancer, it is plausible that SNPs that increase human dietary requirements for choline (in PEMT, $C H D H, B H M T$ or $M T H F D 1$ ) will alter the risk of cancer. An epidemiological study (The Long Island Breast Cancer Study) suggests that high 
dietary choline intake decreases the risk for developing breast cancer and that the PEMT rs 12325817 SNP was associated with a $30 \%$ increased risk of breast cancer mortality (OR: 1.30; 95\% CI: 1.01-1.67) while the BHMT (betaine homocysteine methyltransferase) rs3733890 polymorphism was associated with reduced breast cancer-specific mortality (hazard ratio, 0.64; 95\% confidence interval, 0.42-0.97) [85, 86]. It is interesting that diminished expression of Pemt2, one of two PEMT isoforms in rodent liver, has been reported to occur during hepatocarcinogenesis in rats and in cell culture models [87]. Cell proliferation of the hepatoma-derived cell line, McArdle RH777, which normally has low PEMT activity, was suppressed when transfected with Pemt2 [88]. These hepatoma cells, when transfected with Pemt2, failed to form anchorage-independent colonies in soft agar (a property of cancer transformed cells), while the vector-transfected control cells grew efficiently [89]. In addition, hepatocellular carcinomas induced by the chemical carcinogens aflatoxin B1, diethylnitrosamine or methylnitrosourea had diminished Pemt2 expression and PEMT activity compared with non-tumor liver tissue [87, 89]. This change in PEMT expression and activity was also observed in human hepatocellular carcinomas [90]. Collectively, these studies demonstrate an important role for choline metabolism, and specifically PEMT in cancer. While the mechanism for this cancer-promoting effect of choline deficiency is not fully elucidated, an important component is likely to be the modification of DNA and chromosome structure, mistakes in DNA repair and resulting increased mutation rate.

\section{Acknowledgments}

Supported by funding from the US National Institutes of Health (DK55865 and DK56350).

\section{References}

1. Institute of Medicine, National Academy of Sciences USA. Dietary reference intakes for folate, thiamin, riboflavin, niacin, vitamin B12, panthothenic acid, biotin, and choline. National Academy Press; Washington D.C: 1998. Choline; p. 390-422.

2. Jensen HH, Batres-Marquez SP, Carriquiry A, Schalinske KL. Choline in the diets of the U.S. population: NHANES, 2003-2004. FASEB J. 2007; 21:1b219.

3. Zeisel SH. Choline: Critical Role During Fetal Development and Dietary Requirements in Adults. Annu Rev Nutr. 2005

4. Vance DE, Walkey CJ, Cui Z. Phosphatidylethanolamine N-methyltransferase from liver. Biochimica et biophysica acta. 1997; 1348:142-150. [PubMed: 9370326]

5. Zeisel SH, Mar MH, Howe JC, Holden JM. Concentrations of choline-containing compounds and betaine in common foods. J Nutr. 2003; 133:1302-1307. [PubMed: 12730414]

6. Zeisel SH, Mar M-H, Howe JC, Holden JM. Erratum: Concentrations of choline-containing compounds and betaine in common foods J. Nutr. 133: 1302 1307. J Nutr. 2003; 133:2918-2919.

7. Cho E, Zeisel SH, Jacques P, Selhub J, Dougherty L, Colditz GA, Willett WC. Dietary choline and betaine assessed by food-frequency questionnaire in relation to plasma total homocysteine concentration in the Framingham Offspring Study. Am J Clin Nutr. 2006; 83:905-911. [PubMed: 16600945]

8. Bidulescu A, Chambless LE, Siega-Riz AM, Zeisel SH, Heiss G. Usual choline and betaine dietary intake and incident coronary heart disease: the Atherosclerosis Risk in Communities (ARIC) study. BMC cardiovascular disorders. 2007; 7:20. [PubMed: 17629908]

9. Bidulescu A, Chambless LE, Siega-Riz AM, Zeisel SH, Heiss G. Repeatability and measurement error in the assessment of choline and betaine dietary intake: the Atherosclerosis Risk in Communities (ARIC) study. Nutr J. 2009; 8:14. [PubMed: 19232103]

10. Cho E, Willett WC, Colditz GA, Fuchs CS, Wu K, Chan AT, Zeisel SH, Giovannucci EL. Dietary choline and betaine and the risk of distal colorectal adenoma in women. J Natl Cancer Inst. 2007; 99:1224-1231. [PubMed: 17686825] 
11. Fischer LM, daCosta K, Kwock L, Stewart P, Lu T-S, Stabler S, Allen R, Zeisel S. Sex and menopausal status influence human dietary requirements for the nutrient choline. Am J Clin Nutr. 2007; 85:1275-1285. [PubMed: 17490963]

12. da Costa KA, Niculescu MD, Craciunescu CN, Fischer LM, Zeisel SH. Choline deficiency increases lymphocyte apoptosis and DNA damage in humans. Am J Clin Nutr. 2006; 84:88-94. [PubMed: 16825685]

13. Resseguie M, Song J, Niculescu MD, da Costa KA, Randall TA, Zeisel SH. Phosphatidylethanolamine N-methyltransferase (PEMT) gene expression is induced by estrogen in human and mouse primary hepatocytes. Faseb J. 2007; 21:2622-2632. [PubMed: 17456783]

14. Fischer LM, da Costa KA, Kwock L, Galanko J, Zeisel SH. Dietary choline requirements of women: effects of estrogen and genetic variation. Am J Clin Nutr. 2010; 92:1113-1119. [PubMed: 20861172]

15. Resseguie ME, da Costa KA, Galanko JA, Patel M, Davis IJ, Zeisel SH. Aberrant Estrogen Regulation of PEMT Results in Choline Deficiency-associated Liver Dysfunction. J Biol Chem. 2011; 286:1649-1658. [PubMed: 21059658]

16. da Costa KA, Kozyreva OG, Song J, Galanko JA, Fischer LM, Zeisel SH. Common genetic polymorphisms affect the human requirement for the nutrient choline. Faseb J. 2006; 20:13361344. [PubMed: 16816108]

17. Kohlmeier M, da Costa KA, Fischer LM, Zeisel SH. Genetic variation of folate-mediated onecarbon transfer pathway predicts susceptibility to choline deficiency in humans. Proc Natl Acad Sci U S A. 2005; 102:16025-16030. [PubMed: 16236726]

18. Rushmore TH, Farber E, Ghoshal AK, Parodi S, Pala M, Tanigher M. A choline-devoid diet, carcinogenic in the rat, induces DNA damage and repair. Carcinogenesis. 1986; 7:1677-1680. [PubMed: 3757170]

19. James SJ, Yin L. Diet-induced DNA damage and altered nucleotide metabolism in lymphocytes from methyl-donor-deficient rats. Carcinogenesis. 1989; 10:1209-1214. [PubMed: 2472230]

20. Yoshiji H, Nakae D, Mizumoto Y, Horiguchi K, Tamura K, Denda A, Tsujii T, Konishi Y. Inhibitory effect of dietary iron deficiency on inductions of putative preneoplastic lesions as well as 8-hydroxydeoxyguanosine in DNA and lipid peroxidation in the livers of rats caused by exposure to a choline-deficient L-amino acid defined diet. Carcinogenesis. 1992; 13:1227-1233. [PubMed: 1638691]

21. Pogribny IP, Shpyleva SI, Muskhelishvili L, Bagnyukova TV, James SJ, Beland FA. Role of DNA damage and alterations in cytosine DNA methylation in rat liver carcinogenesis induced by a methyl-deficient diet. Mutation research. 2009; 669:56-62. [PubMed: 19442675]

22. Powell CL, Kosyk O, Bradford BU, Parker JS, Lobenhofer EK, Denda A, Uematsu F, Nakae D, Rusyn I. Temporal correlation of pathology and DNA damage with gene expression in a cholinedeficient model of rat liver injury. Hepatology. 2005; 42:1137-1147. [PubMed: 16250055]

23. Albright CD, Zeisel SH. Choline deficiency causes increased localization of TGF $\beta 1$ signaling proteins and apoptosis in rat liver. Pathobiology. 1997; 65:264-270. [PubMed: 9459496]

24. Coussens LM, Werb Z. Inflammation and cancer. Nature. 2002; 420:860-867. [PubMed: 12490959]

25. Vrablic AS, Albright CD, Craciunescu CN, Salganik RI, Zeisel SH. Altered mitochondrial function and overgeneration of reactive oxygen species precede the induction of apoptosis by 1-Ooctadecyl-2-methyl- rac-glycero-3-phosphocholine in p53-defective hepatocytes. Faseb J. 2001; 15:1739-1744. [PubMed: 11481221]

26. Albright CD, Salganik RI, Craciunescu CN, Mar MH, Zeisel SH. Mitochondrial and microsomal derived reactive oxygen species mediate apoptosis induced by transforming growth factor-beta1 in immortalized rat hepatocytes. J Cell Biochem. 2003; 89:254-261. [PubMed: 12704789]

27. Banni S, Corongiu FP, Dessi MA, Iannone A, Lombardi B, Tomasi A, Vannini V. Free radicals and lipid peroxidation in liver of rats kept on a diet devoid of choline. Free Radic Res Commun. 1989; 7:233-240. [PubMed: 2555277]

28. Ghoshal AK, Farber E. Liver biochemical pathology of choline deficiency and of methyl group deficiency: a new orientation and assessment. Histology \& Histopathology. 1995; 10:457-462. [PubMed: 7599441] 
29. Pacelli C, Coluccia A, Grattagliano I, Cocco T, Petrosillo G, Paradies G, De Nitto E, Massaro A, Persichella M, Borracci P, Portincasa P, Carratu MR. Dietary choline deprivation impairs rat brain mitochondrial function and behavioral phenotype. J Nutr. 2010; 140:1072-1079. [PubMed: 20357080]

30. Guo WX, Pye QN, Williamson KS, Stewart CA, Hensley KL, Kotake Y, Floyd RA, Broyles RH. Mitochondrial dysfunction in choline deficiency-induced apoptosis in cultured rat hepatocytes. Free Radic Biol Med. 2005; 39:641-650. [PubMed: 16085182]

31. Albright CD, Lui R, Bethea TC, da Costa K-A, Salganik RI, Zeisel SH. Choline deficiency induces apoptosis in SV40-immortalized CWSV-1 rat hepatocytes in culture. FASEB J. 1996; 10:510-516. [PubMed: 8647350]

32. Holmes-McNary M, Baldwin J, Zeisel SH. Opposing regulation of choline deficiency-induced apoptosis by p53 and NF-k\{kappa\}B. J Biol Chem. 2001; 276:41197-41204. [PubMed: 11483591]

33. Petrosillo G, Portincasa P, Grattagliano I, Casanova G, Matera M, Ruggiero FM, Ferri D, Paradies G. Mitochondrial dysfunction in rat with nonalcoholic fatty liver Involvement of complex I, reactive oxygen species and cardiolipin. Biochimica et biophysica acta. 2007; 1767:1260-1267. [PubMed: 17900521]

34. Hensley K, Kotake Y, Sang H, Pye QN, Wallis GL, Kolker LM, Tabatabaie T, Stewart CA, Konishi Y, Nakae D, Floyd RA. Dietary choline restriction causes complex I dysfunction and increased $\mathrm{H}(2) \mathrm{O}(2)$ generation in liver mitochondria. Carcinogenesis. 2000; 21:983-989. [PubMed: 10783322]

35. Teodoro JS, Rolo AP, Duarte FV, Simoes AM, Palmeira CM. Differential alterations in mitochondrial function induced by a choline-deficient diet: understanding fatty liver disease progression. Mitochondrion. 2008; 8:367-376. [PubMed: 18765303]

36. Sharpley MS, Shannon RJ, Draghi F, Hirst J. Interactions between phospholipids and NADH:ubiquinone oxidoreductase (complex I) from bovine mitochondria. Biochemistry. 2006; 45:241-248. [PubMed: 16388600]

37. Ohtsuka T, Nishijima M, Suzuki K, Akamatsu Y. Mitochondrial dysfunction of a cultured Chinese hamster ovary cell mutant deficient in cardiolipin. J Biol Chem. 1993; 268:22914-22919. [PubMed: 8226801]

38. James SJ, Cross DR, Miller BJ. Alterations in nucleotide pools in rats fed diets deficient in choline, methionine and/or folic acid. Carcinogenesis. 1992; 13:2471-2474. [PubMed: 1473260]

39. Serviddio G, Bellanti F, Tamborra R, Rollo T, Capitanio N, Romano AD, Sastre J, Vendemiale G, Altomare E. Uncoupling protein-2 (UCP2) induces mitochondrial proton leak and increases susceptibility of non-alcoholic steatohepatitis (NASH) liver to ischaemia-reperfusion injury. Gut. 2008; 57:957-965. [PubMed: 18308829]

40. Marcinek DJ. Mitochondrial dysfunction measured in vivo. Acta Physiol Scand. 2004; 182:343352. [PubMed: 15569095]

41. Johnson AR, Craciunescu CN, Guo Z, Teng YW, Thresher RJ, Blusztajn JK, Zeisel SH. Deletion of murine choline dehydrogenase results in diminished sperm motility. FASEB J. 2010; 24:27522761. [PubMed: 20371614]

42. Brady LJ, Brady PS, Romsos DR, Hoppel CL. Elevated hepatic mitochondrial and peroxisomal oxidative capacities in fed and starved adult obese (ob/ob) mice. The Biochemical journal. 1985; 231:439-444. [PubMed: 4062906]

43. Ghoshal AK, Monserrat AJ, Porta EA, Hartroft WS. Role of lipoperoxidation in early choline deficiency. Exp Mol Pathol. 1970; 12:31-35. [PubMed: 5418073]

44. Rushmore TH, Lim YP, Farber E, Ghoshal AK. Rapid lipid peroxidation in the nuclear fraction of rat liver induced by a diet deficient in choline and methionine. Cancer Lett. 1984; 24:251-255. [PubMed: 6498804]

45. Nakae D. Endogenous liver carcinogenesis in the rat. Pathol Int. 1999; 49:1028-1042. [PubMed: 10632923]

46. Inouye S. Site-specific cleavage of double-strand DNA by hydroperoxide of linoleic acid. FEBS letters. 1984; 172:231-234. [PubMed: 6430718] 
47. Selhub J, Seyoum E, Pomfret EA, Zeisel SH. Effects of choline deficiency and methotrexate treatment upon liver folate content and distribution. Cancer Res. 1991; 51:16-21. [PubMed: 1988081]

48. Varela-Moreiras G, Selhub J, da Costa K, Zeisel SH. Effect of chronic choline deficiency in rats on liver folate content and distribution. J Nutr Biochem. 1992; 3:519-522.

49. Kim Y-I, Miller JW, da Costa K-A, Nadeau M, Smith D, Selhub J, Zeisel SH, Mason JB. Severe folate deficiency causes secondary depletion of choline and phosphocholine in liver. J Nutr. 1994; 124:2197-2203. [PubMed: 7965204]

50. Koury MJ, Horne DW. Apoptosis mediates and thymidine prevents erythroblast destruction in folate deficiency anemia. Proc Natl Acad Sci USA. 1994; 91:4067-4071. [PubMed: 8171036]

51. Stover PJ. One-carbon metabolism-genome interactions in folate-associated pathologies. J Nutr. 2009; 139:2402-2405. [PubMed: 19812215]

52. Meuth M. The relevance of DNA precursor pools to repair. Nucleic Acids Symp Ser. 1984:217229. [PubMed: 6387627]

53. Ayusawa D, Shimizu K, Koyama H, Takeishi K, Seno T. Accumulation of DNA strand breaks during thymineless death in thymidylate synthase-negative mutants of mouse FM3A cells. J Biol Chem. 1983; 258:12448-12454. [PubMed: 6630193]

54. Blount B, Mack M, Wehr C, MacGregor J, Hiatt R, Wang G, Wickramasinghe S, Everson R, Ames B. Folate deficiency causes uracil misincorporation into human DNA and chromosome breakage: implications for cancer and neuronal damage. Proc Natl Acad Sci U S A. 1997; 94:3290-3295. [PubMed: 9096386]

55. Yunis JJ, Soreng AL. Constitutive fragile sites and cancer. Science. 1984; 226:1199-1204. [PubMed: 6239375]

56. Mehedint MG, Niculescu MD, Craciunescu CN, Zeisel SH. Choline deficiency alters global histone methylation and epigenetic marking at the Re1 site of the calbindin 1 gene. Faseb J. 2010; 24:184-195. [PubMed: 19752176]

57. Niculescu MD, Craciunescu CN, Zeisel SH. Dietary choline deficiency alters global and genespecific DNA methylation in the developing hippocampus of mouse fetal brains. Faseb J. 2006; 20:43-49. [PubMed: 16394266]

58. Pogribny IP, Ross SA, Wise C, Pogribna M, Jones EA, Tryndyak VP, James SJ, Dragan YP, Poirier LA. Irreversible global DNA hypomethylation as a key step in hepatocarcinogenesis induced by dietary methyl deficiency. Mutat Res. 2006; 593:80-87. [PubMed: 16144704]

59. Pogribny IP, Miller BJ, James SJ. Alterations in hepatic p53 gene methylation patterns during tumor progression with folate/methyl deficiency in the rat. Cancer Lett. 1997; 115:31-38. [PubMed: 9097976]

60. Niculescu MD, Yamamuro Y, Zeisel SH. Choline availability modulates human neuroblastoma cell proliferation and alters the methylation of the promoter region of the cyclin-dependent kinase inhibitor 3 gene. J Neurochem. 2004; 89:1252-1259. [PubMed: 15147518]

61. Esfandiari F, Green R, Cotterman RF, Pogribny IP, James SJ, Miller JW. Methyl deficiency causes reduction of the methyl-CpG-binding protein, MeCP2, in rat liver. Carcinogenesis. 2003; 24:1935-1940. [PubMed: 12949043]

62. Kovacheva VP, Mellott TJ, Davison JM, Wagner N, Lopez-Coviella I, Schnitzler AC, Blusztajn JK. Gestational choline deficiency causes global and Igf2 gene DNA hypermethylation by upregulation of Dnmt1 expression. J Biol Chem. 2007; 282:31777-31788. [PubMed: 17724018]

63. Waterland RA, Jirtle RL. Transposable elements: targets for early nutritional effects on epigenetic gene regulation. Mol Cell Biol. 2003; 23:5293-5300. [PubMed: 12861015]

64. Waterland RA, Dolinoy DC, Lin JR, Smith CA, Shi X, Tahiliani KG. Maternal methyl supplements increase offspring DNA methylation at Axin fused. Genesis. 2006; 44:401-406. [PubMed: 16868943]

65. Loughery JE, Dunne PD, O'Neill KM, Meehan RR, McDaid JR, Walsh CP. DNMT1 deficiency triggers mismatch repair defects in human cells through depletion of repair protein levels in a process involving the DNA damage response. Hum Mol Genet. 2011; 20:3241-3255. [PubMed: 21636528] 
66. Kim M, Trinh BN, Long TI, Oghamian S, Laird PW. Dnmt1 deficiency leads to enhanced microsatellite instability in mouse embryonic stem cells. Nucleic Acids Res. 2004; 32:5742-5749. [PubMed: 15509869]

67. Gonzalo S, Jaco I, Fraga MF, Chen T, Li E, Esteller M, Blasco MA. DNA methyltransferases control telomere length and telomere recombination in mammalian cells. Nat Cell Biol. 2006; 8:416-424. [PubMed: 16565708]

68. FitzGerald J, Moureau S, Drogaris P, O'Connell E, Abshiru N, Verreault A, Thibault P, Grenon M, Lowndes NF. Regulation of the DNA damage response and gene expression by the Dot $1 \mathrm{~L}$ histone methyltransferase and the 53Bp1 tumour suppressor. PLoS ONE. 2011; 6:e14714. [PubMed: 21383990]

69. Fnu S, Williamson EA, De Haro LP, Brenneman M, Wray J, Shaheen M, Radhakrishnan K, Lee $\mathrm{SH}$, Nickoloff JA, Hromas R. Methylation of histone H3 lysine 36 enhances DNA repair by nonhomologous end-joining. Proc Natl Acad Sci U S A. 2011; 108:540-545. [PubMed: 21187428]

70. Albright CD, Mar MH, Friedrich CB, Brown EC, Zeisel SH. Maternal choline availability alters the localization of p15Ink4B and p27Kip1 cyclin-dependent kinase inhibitors in the developing fetal rat brain hippocampus. Dev Neurosci. 2001; 23:100-106. [PubMed: 11509832]

71. Steinmetz KL, Pogribny IP, James SJ, Pitot HC. Hypomethylation of the rat glutathione Stransferase pi (GSTP) promoter region isolated from methyl-deficient livers and GSTP-positive liver neoplasms. Carcinogenesis. 1998; 19:1487-1494. [PubMed: 9744547]

72. da Costa KA, Garner SC, Chang J, Zeisel SH. Effects of prolonged (1 year) choline deficiency, subsequent refeeding of choline on 1,2,-sn-diradylglycerol, fatty acids and protein kinase $\mathrm{C}$ in rat liver. Carcinogenesis. 1995; 16:327-334. [PubMed: 7859365]

73. da Costa K, Cochary EF, Blusztajn JK, Garner SC, Zeisel SH. Accumulation of 1,2-sndiradylglycerol with increased membrane-associated protein kinase $\mathrm{C}$ may be the mechanism for spontaneous hepatocarcinogenesis in choline deficient rats. J Biol Chem. 1993; 268:2100-2105. [PubMed: 8420980]

74. Chandar N, Lombardi B. Liver cell proliferation and incidence of hepatocellular carcinomas in rats fed consecutively a choline-devoid and a choline-supplemented diet. Carcinogenesis. 1988; 9:259263. [PubMed: 3338109]

75. Goshal AK, Farber E. The induction of liver cancer by dietary deficiency of choline and methionine without added carcinogens. Carcinogenisis. 1984; 5:1367-1370.

76. Nakae D, Yoshiji H, Mizumoto Y, Horiguchi K, Shiraiwa K, Tamura K, Denda A, Konishi Y. High incidence of hepatocellular carcinomas induced by a choline deficient L-amino acid defined diet in rats. Cancer Res. 1992; 52:5042-5045. [PubMed: 1516060]

77. Shinozuka H, Lombardi B. Synergistic effect of a choline-devoid diet and phenobarbital in promoting the emergence of foci of $\gamma$-glutamyltranspeptidase-positive hepatocytes in the liver of carcinogen-treated rats. Cancer Res. 1980; 40:3846-3849. [PubMed: 6108159]

78. Yokota K, Singh U, Shinozuka H. Effects of a choline-deficient diet and a hypolipidemic agent on single glutathione S-transferase placental form-positive hepatocytes in rat liver. Jpn J Cancer Res. 1990; 81:129-134. [PubMed: 2110129]

79. Denda A, Kitayama W, Kishida H, Murata N, Tsutsumi M, Tsujiuchi T, Nakae D, Konishi Y. Development of hepatocellular adenomas, carcinomas associated with fibrosis in C57BL/6J male mice given a choline-deficient, L-amino acid-defined diet. Jpn J Cancer Res. 2002; 93:125-132. [PubMed: 11856475]

80. Ghoshal AK, Farber E. The induction of liver cancer by dietary deficiency of choline and methionine without added carcinogens. Carcinogenesis. 1984; 5:1367-1370. [PubMed: 6488458]

81. Rogers AE, Zeisel SH, Groopman J. Diet and carcinogenesis. Carcinogenesis. 1993; 14:22052217. [PubMed: 8242845]

82. Lanari C, Lamb CA, Fabris VT, Helguero LA, Soldati R, Bottino MC, Giulianelli S, Cerliani JP, Wargon V, Molinolo A. The MPA mouse breast cancer model: evidence for a role of progesterone receptors in breast cancer. Endocr Relat Cancer. 2009; 16:333-350. [PubMed: 19190078]

83. Rogers AE, Akhtar R, Zeisel SH. Procarbazine carcinogenicity in methotrexate-treated or lipotrope-deficient male rats. Carcinogenesis. 1990; 11:1491-1495. [PubMed: 2401040] 
84. Schrager TF, Newberne PM, Pikul AH, Groopman JD. Aflatoxin-DNA adduct formation in chronically dosed rats fed a choline-deficient diet. Carcinogenesis. 1990; 11:177-180. [PubMed: 2104783]

85. Xu X, Gammon MD, Zeisel SH, Bradshaw PT, Wetmur JG, Teitelbaum SL, Neugut AI, Santella RM, Chen J. High intakes of choline and betaine reduce breast cancer mortality in a populationbased study. Faseb J. 2009; 23:4022-4028. [PubMed: 19635752]

86. Xu X, Gammon MD, Zeisel SH, Lee YL, Wetmur JG, Teitelbaum SL, Bradshaw PT, Neugut AI, Santella RM, Chen J. Choline metabolism and risk of breast cancer in a population-based study. FASEB J. 2008; 22:2045-2052. [PubMed: 18230680]

87. Tessitore L, Dianzani I, Cui Z, Vance DE. Diminished expression of phosphatidylethanolamine Nmethyltransferase 2 during hepatocarcinogenesis. Biochem J. 1999; 337(Pt 1):23-27. [PubMed: 9854020]

88. Cui Z, Houweling M, Vance DE. Suppression of rat hepatoma cell growth by expression of phosphatidylethanolamine N-methyltransferase-2. J Biol Chem. 1994; 269:24531-24533. [PubMed: 7929120]

89. Tessitore L. Apoptosis and cell proliferation are involved in the initiation of liver carcinogenesis by a subnecrogenic dose of diethylnitrosamine in refed rats. J Nutr. 2000; 130:104-110. [PubMed: 10613775]

90. Tessitore L, Marengo B, Vance DE, Papotti M, Mussa A, Daidone MG, Costa A. Expression of phosphatidylethanolamine N-methyltransferase in human hepatocellular carcinomas. Oncology. 2003; 65:152-158. [PubMed: 12931022] 


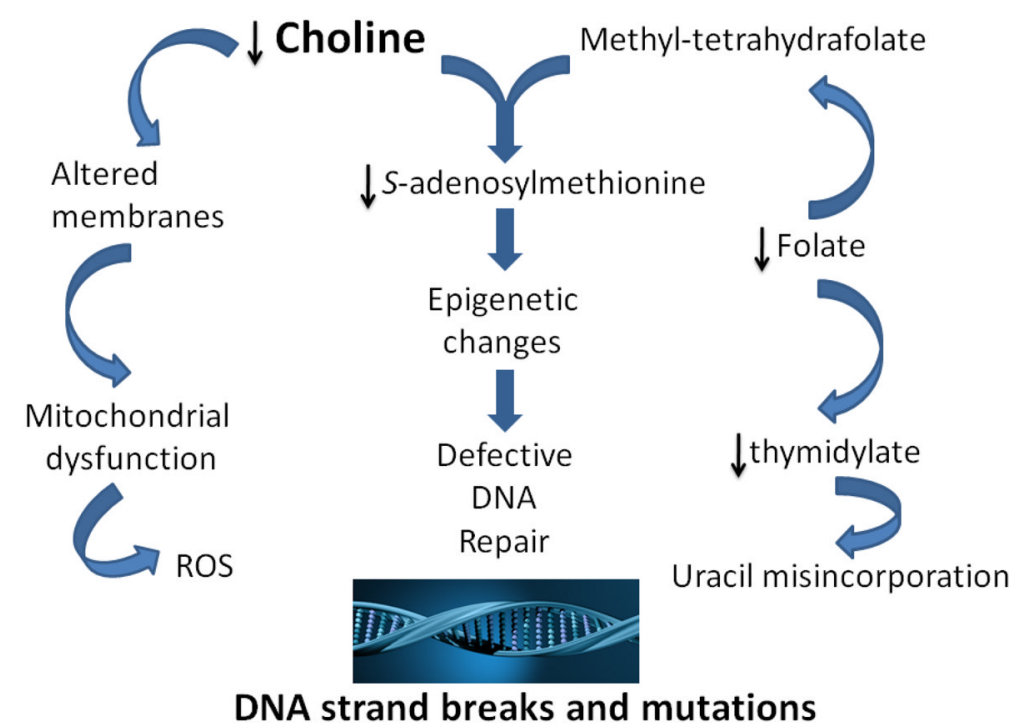

Figure 1. Mechanisms for effects of choline deficiency on DNA strand breaks and mutation Choline deficiency increases leakage of reactive oxygen species from mitochondria consequent to altered mitochondrial membrane composition and enhanced fatty acid oxidation. Choline deficiency impairs folate metabolism, resulting in decreased thymidylate synthesis and increased uracil misincorporation into DNA, with strand breaks resulting during error-prone repair attempts. Choline deficiency alters DNA methylation, which alters gene expression for critical genes involved in DNA mismatch repair, resulting in increased mutation rates. 